Instructions for authors, subscriptions and further details:

http://rimcis.hipatiapress.com

\title{
Untold Stories: A Study of Sudanese and Syrian Refugees in Estonia
}

Aminul Islam ${ }^{1}$

1) Tallinn University, Estonia

Date of publication: March $30^{\text {th }}, 2020$

Edition period: March 2020 - July 2020

To cite and link this article: Islam, A. (2020). Untold Stories: A Study of Sudanese and Syrian Refugees in Estonia. International and Multidisciplinary Journal of Social Sciences, 9(1), 1-25. http://doi.org/10.17583/rimcis.2020.5131

\section{PLEASE SCROLL DOWN FOR ARTICLE}

The terms and conditions of use are related to the Open Journal System and to Creative Commons Attribution License (CC-BY). 


\section{Untold Stories: A Study of Sudanese and Syrian Refugees in Estonia}

Aminul Islam

Tallinn University

\section{Abstract}

The aim of this study was to explore the coping resources and the present and past experiences of two groups with refugee experiences in Estonia through narrative approach. Avert narratives, Struggling narratives, Instantaneous narratives, Boundary narratives, and Re-occurrence narratives identified through the interviews with 12 refugees. Differences between this two groups and individual accounts were also identified. The structure of the narratives, identity construction while in exile and coping mechanism through the narratives shaped their life stories and lives in exile. One significant outcome of this study is the lack of compatibility of the stories between two groups, through which five narratives established to elaborate the variety of their accounts.

Keywords: refugee, Estonia, narrative, memory, story 


\section{Historias No Contadas: Estudio de Refugiados Sirios y Sudaneses en Estonia}

Aminul Islam

Tallinn University

\section{Resumen}

El objetivo de este estudio fue explorar los recursos de afrontamiento y las experiencias presentes y pasadas de dos grupos con experiencias de refugiados en Estonia a través del enfoque narrativo. Las narrativas de evitación, las narrativas de lucha, las narrativas instantáneas, las narrativas de límites y las narrativas de reaparición identificadas a través de las entrevistas a doce refugiados. También se identificaron las diferencias entre estos dos grupos y los testimonios individuales. La estructura de las narrativas, la construcción de la identidad en el exilio y el mecanismo de afrontamiento a través de las narraciones moldearon sus historias de vida y sus vidas en el exilio. Un resultado significativo de este estudio es la falta de compatibilidad de las historias entre dos grupos, a través de las cuales se establecieron cinco narrativas para elaborar la variedad de sus relatos.

Palabras clave: refugiados, Estonia, narrativa, memoria, historia 


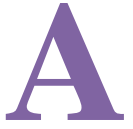

ccording to Teski and Climo (1995) storytelling belongs to those activities that makes us human. Told stories often become the changes that occur over a period of time. How we construct our identity is complex phenomenon and never happens in isolation, but it is a process which can be called interactive and directed towards the stories told by the participants for a large audience (Goffman, 2002). It does not mean that people's identities are not authentic, rather it gives the plural and vocal nature of identity which has influence of the individual's or the narrator's past, present and future through their social, cultural, historical, family or political aspects (Feuchtwang, 2003).

Riessman in the year 2008 in his study of refugee stories stated that when people tell their stories of their lives, they actually live with those stories what they tell. Any disruptions of life, which leads separation from family members and be associated with force migration and then the ultimate result is the loss of country and home. To cope with the new environments and to reconstruct identity, stories that the refugees hold and to give them the space of telling that could assist them in creating new identities in terms of home and host society and culture and to gain control of their new lives in a foreign land (Leydesdorff, 2000; Frank, 2010).

However, many studies on the other hand pointed out that traumatic experiences could interfere memories, which could lead the refugees preventing to associate memories, which could make them unable to adapt new experiences (Keyes \& Kane, 2004; Obrist \& Buchi, 2008; Weingarten, 2003). Stories related to traumatic memories are not pleasant and sometimes people try to suppress these unpleasant memories, their thoughts and actions related to traumatic experiences (Herman, 2001) and if they share their experiences negatively and it makes effect to their identity or their any wellbeing, then to avoid or suppress their stories gets validated (Anderson et al., 2010). However, Herman (2001) pointed out that retelling and revising stories help people to organize and integrate their fragmented experiences or memories, which could create new coherent narratives and ultimate helps to get rid of post-traumatic experiences. This way, people could select their past as memory which is very dynamic in everybody's mind, filter them and then restructure them in terms of present situation and future needs. This 
process also creates an environment to create counter narratives to heal them from the experiences, at the same time keeping the values of their self and family. Counter narrative can be defined in a way which challenges the dominant view of a given society, as often refugees are viewed as traumatized people and can be burden for the society (Herman, 2001).

\section{Memory and Narrative}

Participants memory plays important role to build narratives (Halbwachs, 1980). It is often considered that memories reflect one's self reflection, but also has social aspects in it (Bneezer, 2002). It is often highlighted that refugees should forget their past to be able to cope with their new societies, hence instead of past memories, it is expected that refugees should focus on the new memories (Teski \& Climo, 1995). In this regard it is important for researchers and social scientists to pay attention to memories that are not being heard. If untold memories are acknowledged, researchers would be able to come up with new ideas to address refugee issues (Feuchtwang, 2003).

Language play significant role in sharing memories, through which their past images comes into social construction (Leydesdorff, 2000). The link between language and memories has been emphasized by the researchers (Alexander, 1995) to reflect refugee lives. Metaphors that come through language reflects their stories and play important role to illustrate refugees daily life (Burner, 1987). Self identity can be recognized through shared language and thoughts (Linde, 1987)

It is believed that cultural symbols can be addressed through shared language and narratives through which refugee's past and present can be analyzed (Cavarero, 2000). Often told narratives expressed by an individual is viewed as complete personal aspect but the path it came through, the sense of vibration it creates, the language being used gives us the cultural narratives of which any individual is exposed (Bneezer, 2002).

Social class can also be found and analyzed by the narratives told by the participants (Tonkin, 1992) and it usually depends on the selections of the plots and themes and which way we want to recall their lives and memories. George Steinmetz (1992) for instance stated that themes that are the creation 
of told stories through language are actually the reflection of culture, gender or race. To be able to acknowledge their sense of identity, told narratives play vital role and is significant to know the any society where we live. (Dawson, 1994) It is not that all the told stories help to understand the culture but the sequential path that it follows and its life cycle gives us the plot to understand it (Andrews, 2004). Tonkin (1992) in a study on Jlao community in Liberia stated that same stories can have several meanings, therefore it is important to understand the plot to be able to illustrate the complete situation. Gleason (1983) stated that our self-hood is a reflection of the society where we belong and its values. Our memory this way becomes the major source of our identity and then the changes that we make in our life are the the narratives from within a story being told.

\section{Migration and Memory}

Sense of belonging and the space they belong is very significant for migrants and it comes from the memory that they carry and their imagination (Constance, 2004). For transnational families, narratives play vital role to form their identity (Appadurai, 1996), which can reflect how they adapt in a new society. In a study on Christian refugees, Bryceson and Vuroela (2002) figured how gender and status of migrant can play different role in sharing memories. The role of male and female can also be changed in a different context as Thompson and Bauer (2005) pointed out that the role of a migrant father was changed in a different country context and was explained completely different way while telling stories.

Family dynamics can be presented through oral stories. In a study on African Caribbean families, Constance (2004) pointed out that family reunion and constant communication with family members back home is significant for migrant families which provide them the sense of belonging and also identity practice. It is often viewed that knowing family is knowing themselves and shared memories play a significant part in it. Shared life stories provide an individual to express the sense of emotion which in turn could help in adapting a new society (Nussbaum, 2001). 


\section{Context of Estonia}

Estonia recently transformed from a refugee producing country to a refugee hosting country (Tammaru et al., 2010). The number of applicants started to increase in the year 2010 but reached at its peak in the year 2015, when the number of asylum seekers were 230. However, by the end of 2018, there were 322 refugees living in Estonian (UNHCR, 2018). Estonia also agreed to accept quota refugees as part of European relocation program and these refugees are from Non- European ethnic background. Islam (2016) in his study on Estonian refugees, pointed out that there is no significant academic research on existing refugees from outside Europe, Estonia will start to receive quota refugees from non-European ethnic background. Therefore, academics and researchers need to address this issue to integrate these refugees into the host society.

\section{Aim of This Study}

Any groups or community in a society, which are marginalized need to have adequate space, so they can tell their stories at a pace which can be conducive for them. Researchers duty is to move beyond the words and to extract the silences and blank untold stories (Sorsoli, 2010). To explore silences and untold stories, unstructured life story method is suitable for the researchers, as it allows bringing out the counter narratives through long conversations, which allows the narrators to reveal their stories (Ward, 2003).

Spector-Mersel (2011) proposed a narrative interpretive model to find out the identity of the narrators and according to him it can be revealed by the Narratives end point (EP), researchers need to attend or focus on what is added in the stories and what is excluded. To be able to come up with the end point (EP), one needs to take the silences (what is excluded), omissions (were irrelevant), and flattening (were told but not elaborated) into account to reconstruct identity, which can be suitable for themselves.

By studying specific settings, this study aimed to explore the coping resources and the present and past experiences of two groups with refugee experiences in Estonia through narrative approach. 


\section{Methodology}

\section{Participants}

Participants having refugee status were from Syria (seven) and Sudan (five) and they are living in Estonia. Among the participants, eight were men and four women aged between 21 and 57 years. Participants from Sudan's average age was 34 and Syrian participant's average was 36 years. There was not any feasible difference between these participants on the basis of age or how many years they are in Estonia. To ensure the confidentiality of the participants, their individual particularities will not be provided.

To gain the access of the participants, contact was established with the support person, who provides various support to resettle refugees in Estonia. Once the contact was made, some participants referred their friends who they believed will be willing to share their stories.

Participants were well-informed about the research the perspectives of this study. Participants gave the consent to audio-taping. However, as this study was carried out in a refugee center, according to the center's rules and regulations, I was not allowed to carry any audio-taping out of the center. So, I had to transcribe the data before I left the center. Participants from Sudan was more heterogeneous, in terms of religion and education, two of them had university degree and three of them are Christian and two Muslim, whereas participants from Syria are all Muslim and there were no one who had university degree. However, all participants were educated and had good level of English, when it comes to communicate.

\section{Data collection}

Open ended face to face interviews were carried out between December 2016 and March 2017 at Vao Keskus. This is the place where asylum seekers and refugees are placed in Estonia. However, they were asked to choose their preferred venue, so they feel comfort to express their stories, and they preferred to have it where they live. Interviews were mostly done in about one hour to three hours session. Their life stories were collected through unstructured interviews, starting with an opening statement and then 
follow up questions for clarifications to enhance understanding. All interviews begun with the statement: Please tell me your life story in your way. You can start with your life back your home country and then continue your stories as your journey continued till Estonia, your first experiences in Estonia and the later time and what you frame for future life.

\section{Data Analysis}

To analyze the stories, a case-centered narrative approach was used (Riessman, 2008). Interviews were transcribed and checked carefully. Next step was to describe interviews thematically, this way a structural element of narratives identified to get the main points of the stories and overall context of the study-who, when and where; to evaluate the emotional perspectives of the narrator (Labov, 2008) The aim of the analysis was to present the holistic interpretation of each told story which included individual, socio-cultural, interpersonal influences (Josselson, 2011). Any ambiguities that arose of this study were discussed with the participants. However, respondents' names and any aspects that might reveal their circumstances were omitted to preserve their confidentiality.

\section{Analysis}

Participants of this study were asked to tell their story in their words to feel comfort while sharing. Participants from Sudan explained their stories in an order and stories were equally distributed while described their life in Sudan and then exile time to Estonia. Their stories contained powerful feelings and clear image of their events and experiences that they have gone through in different stages. Stories from Syrian refugees on the other hand were not told systematically when it came to share their stories in their country of origin to the country where they are relocated now. Most of their stories were not concentrated on their homeland, concerning conflicts and war related experiences. However, follow up questions drove them to gain momentum and to express their stories on conflicts and war situation.

Considering this variance within this two groups, some individual were also identified concerning the structure of the respondent's narrative and 
accordingly five narratives emerged through told stories: avert narratives, Struggling narratives, Instantaneous narratives, Boundary narratives, and reoccurrence narratives.These narratives have been emerged by using Grounded theory as it provides flexible guidelines to explore and analyze data (Thornberg \& Charmaz, 2014).

\section{Avert Narratives: 'I am from Syria and then I moved to live in Turkey'}

Syrian narratives had small accounts of their home land and war related experiences. Syrian narratives were reluctant to elaborate their conflict related experiences, it can be the reason that they want to avoid these stories, which can affect their mental well-being. Sayeed, a 32 years Syrian, left his country when he was 29 , he described his story of his life in his home country shortly:

\section{Extract 1}

1. I was living in Syria with my family and friends

2. Conflict begun in Syria

3. Then I was forced to go abroad

4. It was not for holidays, only to find myself in a refugee camp

This respondent described his life in his country of origin in few sentences $(1.1,1.2)$, hence the narratives of his home country and war related story has not been well formulated. Family and friends however has been a hint (1.1), which can be extracted in regard to life at home. War related story plot can be elaborated in relation to the consequences of forced migration (1.4) and it was not for any amusement or holidays, but no elaboration of the experiences is formed. On the other hand, when explained the life in Estonia, many descriptions are offered as from Extract 2.

\section{Extract 2}

1. Initial period was difficult for many reasons...

2. I do not know local language.

3. I have no friends and relatives...

4. I cannot share anything with anybody, no help from anybody. 
5. No one talks here, so cold and dark...

6. I do not see any people on the street, culture is different.

7. It is completely a different country.

Respondent in this extract shared his difficulties and described it clearly $(2.1,2.2,2.3,2.4,2.5,2.6)$ in contrast to the first Extract. Language problem and not having family members and friends (2.1 and 2.3) to share his struggle can be understood. Climate differences and cultural barrier is mentioned clearly (2.5 and 2.6) and while it was shared, way of expressing the stress was clearly evident. His experiences in Estonian was clearly described and later his thoughts about future in Estonia was also well described in contrast to the narratives in Homeland.

Sayeed, time to time went back to share his thoughts on how his life was back home in regard to life before war and how nice it was to compare life that he is leading abroad but then his comments on life back home was very brief with almost no detail description to evaluate his thoughts and was not offered to narrativize his life during the and after the war.

Other respondents from Syria were likewise reluctant to share their narratives of war. They shortly described where they are from and then proceeded their life in exile as Rafal a 27-year man described 'I was 24 when I left Syria and then from there, I moved to Turkey to Europe.' Even while asked to describe their story at home, the account was brief as follow:

\section{Extract 3}

1. Can you remember your stories in the war period and the journey that you had till Estonia?

2. Yes, I can remember very well.

3 . Could you share your stories?

4. I had to spend money to leave and to reach Europe and the brokers took all before I reached to Europe and when I was sent to Estonia, I had nothing that I took from home.

5. I am still lucky I made it here. It was a horrible journey.

Rafal came to Estonia, and he had to spend more than three thousand euro to cross the sea to reach Europe in the first place. Here it is again 
evident that no description was provided in regard to life in Syria and war narratives. Journey towards Estonia is described (3.4) as he mentioned it was 'horrible' but any description of horrible experiences is mentioned other than 'they took away all.' However, most of the Syrian refugees described their challenges of their initial period being exile and their hopes for the future, it can be extracted from this Extract (3.5) as he mentioned 'I am lucky I am alive and made it here', which shows her desire to life and to focus on her future life.

\section{Tussle Narratives: 'Everything was gone in a moment...people died, screamed around'}

Since the Syrian Narratives of their life back home was almost non-existent, some follow up questions were utilized to elaborate their description but at the same time participant's willingness to express their own narrative was respected. In doing that so, nonverbal expressions have been taken into account. It is also understood that sometimes refugees try to avoid their distressing experiences and often think of their pleasant life before the conflict or before war begun as their coping device to go forward. Some studies have focused on how refugees made their effort to forget their previous memories and to concentrate on their current situation and to keep up their hope for the future. Children future, education and safety and successful life made them optimistic to adapt elder generation into a new societal context and at the same time think of their homeland before war (Hoot, 2011; Roxas, 2011; Este \& Tachble, 2009). This particular aspect is also supported by the interviews with the Sudanese. However, Syrian narratives differ from this pattern, as illustrated below:

\section{Extract 4}

1. Can you tell me your life in Syria?

2. Sure...

3. Life was so good but then the war......people screaming, dying, and things that I never saw before...

4. What about your life before conflict broke? 


\section{Aminul Islam - Refugees and Untold Stories}

5. I had my parents, they had good job.... I had my brothers, they were studying...

6. They all died, only I survived...

7. I went to the refugee camp in Turkey all alone and it was difficult....

Rafal's war related narratives are not yet developed from this extract, possibly it was because he became too emotional to express. He informed his family member's death (4.6) but did not elaborate how it all happened. He described the event, but he did not explain the circumstances behind and surrounding that. His emotion of losing all family members and how he spent time afterwards and what are the 'difficulties' was not elaborated. At the same time, it is to state that the nonverbal expression conveyed his emotion. Rafal's narratives slowly got into exile as he mentioned 'only I survived' (4.6) despite the fact that in the Extract 3 he mentioned 'I am lucky that I made it' but his narrative in this extract elaborated his difficulties in the camp and the journey being all alone. There is significant difference of narrative structure-willingness to narrate Syrian narratives are not wellformed, whereas narratives of exile are well-formed.

\section{Instantaneous Narrative: 'It is a never-ending story'}

Zara's narrative a 21-year Syrian girl can be considered as an exception. She also started her story quickly going through life in Syria in saying one or two sentences, ending her remark 'what else!' When prompted by the interviewer to describe her childhood by utilizing the same technique as Rafal's case, she changed her mood into a nostalgic account of how she spent her childhood with family and friends, which then moved to her feelings and thoughts to make it a well-developed narrative:

\section{Extract 5}

1. I left Syria 4 years before when it was impossible to live ...

2. What else!

3. What about your childhood in Syria?

4. Life was peaceful and good.

5. Anything else that you can remember? 
6. We were living like a free bird

7. I had my family, friends, relatives

8. I could visit to my neighbours family

9. Many events around to have fun with others

10. I grew up in a friendly environment.

11. Everything was great.

The progression is somewhat similar to Rafal's narrative which drove to the war and conflict situation in the next extract on conflict life chaos and tough experiences.

\section{Extract 6}

1. Then the conflict started

2. Then war broke out...

3. Trying to look for shelter

4. You don't know where you are heading

5. Can you remember?

6. Yes, I can.... sometimes it just comes and go...all the scenes ...

7. When I close my eyes off.... it's like watching a video

8. People running around....

9. Screaming, and I could have been killed

10. It is a never-ending story......

Zara's account of Syrian war is short, when prompted by the interviewers to elaborate she switched to a mode to express how it how she feels on her stress experiences by saying 'Yes, I can, sometimes it just comes and go. '(6, 6) She finally attempted to describe war related narrative by expressing (6.8, 6.9), it was however not a fluent elaboration. When she was asked- 'can you remember', she said- Yes, I can, then she described how she feels (6.7) instead of describing what she recalled. Finally, her war related story moved to a point of fear narrative (6.9) and then she quickly returned to the present narrative as she mentioned, it is a never-ending story (6.10), instead of elaborating her never ending narrative, she moved to narrate her present situation. 


\section{Aminul Islam - Refugees and Untold Stories}

\section{Boundary Narrative: 'I do not want to share details about it now'}

Despite the fact that the participants from Sudan expressed their war related traumatic events very organized way in detailing what they witnessed, yet they expressed a point of disclosure to get into detail, so they do not feel distressed. Awchake a 35- year man expressed his narrative

\section{Extract 7}

1. I am Awchake.... my stories during the conflict period that lived my life....

2. I don't know whether it was war or conflict, but it was horrible. I may not be able to provide all information ...

3. However, I will try to recall the basics with sequence

4. But I do not want to provide details as I will feel stress out later then.

Awchake has expressed his stories in the war period with an afford to make it descriptive narrative by explaining his experiences of traumatic events, how he was tortured, female members being raped, fear of abduction, he even expressed that he witnessed killings, homes being burned, how chaos broke out, people looting even from neighbour's home. In order to validate his account, he even revealed some of the marks of him being tortured. It is a detailed war related narrative of which he tried to orient his audience. He ended up his Sudanese narrative by stating how he escaped and fled to the neighbour country and for that he is thankful to his God. Awchake's homeland narratives can be intertwined by his religious beliefs as he stated God help many times. His statement of not to get into details (7.5) can be elaborated with the fact of protecting himself and to avoid potential invasive questions or interruptions which actually in turn prompted to form his own narratives. 


\section{Re-occurrence/coming-going back Narratives: I keep on thinking people are being killed, houses are burnt.}

Sudanese narratives on their trauma experiences expressed repeatedly, sometimes because of the question that the interviewer asked and sometimes it came spontaneously to describe their homeland narratives. Reagan who was 29, when he left Sudan described how he lost his home, when rebellion came and destroyed his house and killed his parents, he survived and ran away without knowing where he was heading and the fortune of his other family members. He fled to a refugee camp and finally reached to Estonia. While explaining his post migration narrative, he went back to describe his stories of how he escaped Sudan:

\section{Extract 8}

1. I have no one here.

2. I don't even know what happen to my other family members

3. I keep on thinking people are being killed, houses are burnt...

4. Dead bodies around....and you walk through them...

5. These memories will never die out from my mind...

Reagan started with his account of his present life and his feeling of being alone (8.1) and to have some of his loved ones around, when he doesn't know what happened to them (8.2). Then he proceeded to return to his homeland narratives by describing his account of traumatic event (8.3, 8.4), even though it is not totally well-formed narrative but the illustration of his traumatic experiences are expressed through 'you walk through them.' As one of the aims of this study was to explore the coping mechanism, hence Reagan was asked how he went past these experiences, Reagan described about his mental state of affairs in relation to his experiences with the consultant.

\section{Extract 9}

1. I don't really think counselling works...

2. Some questions, I do not want to answer 
3. Sometimes I found it strange when she asked questions which I do not want to deal with

4. They keep me back to the home memories...

5. You do not want to keep saying how you could have been slaughtered

6. So, I did not continue...

His account of counselling was on a negative note (9.1, 9.2, 9.3, 9.5, 9.6) while asked about counselling and how it helped in coping, he again returned to his conflict related narrative. This extract also provides the fact that lack of proper psychological counselling which is needed to apply for particular group of people.

At the end of this long interview, when asked about his religious belief and how it helped in coping during his exile period, Reagan progressed very organized way and his description came spontaneously. He described how it makes a sense of his life to go forward throughout his journey from war to exile:

\section{Extract 10}

1. We pray, because that gives us some kind of hope.

2. When houses are burnt, people are being killed, you still pray

3. You don't know whether you will make it...

4. I am a Christian, so I know God has a purpose to send me...

5. There should be a meaning of life...

6. So, I am not going to give up. I will keep on running...

Sudanese account of religious belief helped them to look forward, many times their description took them to return repeatedly of their homeland narratives (10.2). In the end of the long interview with the participants from Sudan, many of them expressed that they never shared their stories with anybody, and their stories have never been told. Regan for instance said- he never had the chance to share his stories related to trauma with his own community people, as they all have their own stories, so he never wanted to give them something extra, which can again affect them to recall their tough memories. 
Elori a 23 years Sudanese girl for instance expressed her detailed narrative on how she fled her country, her school days back home, and friends, her studies in Estonia and future thoughts. She elaborated the event when she lost her only brother while in exile. Elori's narrative ended with following:

\section{Extract 11}

1. My brother was the only member from my family who I can share things...

2. I had nothing to do, just to observe my brother passed away...

3. There was no funeral, we just buried him...

4. Then I realized, I have lost...

5. I think this is the first time I am talking about my brother...

Interview with Elori conveyed how she felt when she lost her brother and the shock 'I have lost.' $(11.1,11.2,11.3,11.4)$ Her fragmented sentences indicates the emotion narrative. She one point mentioned 'sorry for being emotional' indicates that she did not want to express her emotion but as she mentioned 'I think this is the first time I am talking about my brother' indicates she was overwhelmed by the event and her account of loneliness can be observed.

\section{Discussion}

Interviews with the respondents produced five narratives of Avert narratives, struggling narratives, Instantaneous narratives, Boundary narratives, and Reoccurrence narratives. Participants were more fluent in elaborating their narratives of exile, life in Estonia than expressing their homeland and war narratives. Syrian participants were more reluctant in expressing their stories on war and conflict, whereas Sudanese narratives were more descriptive and elaborative.

Avert narratives were dominated by the accounts of Syrian participants who were silent in expressing their war related experiences. However, participants from both Sudan and Syria struggled to share their elaborate experiences of conflict related stories, which is however somewhat related to 
the fact that it can impact negatively of their trauma narratives (Bneezer, 2002). Syrian narratives appeared more segmented than Sudanese narratives as it appeared that Syrian quickly mentioned their homeland narratives in one or two sentences and then moved to the next narratives on life in Estonia. Sudanese narratives appeared more organized and elaborated starting from homeland to exile but at the same time it appeared boundary line narratives in elaborating trauma related experiences. War related narratives still appeared less described but was more elaborated when prompted by the interviewer.

Religious and spiritual aspects appeared a measure of adaptation while in exile or difficult situation. Sudanese narratives appeared very strong in spiritual aspects as one respondent mentioned 'I am a Christian, so I know God has a purpose to send me', which can also be supported by the other studies. Religion is quite close to cultural aspect, thus create a guide of feelings, thoughts and somewhat associated with identity. It might sound as an individual coping strategy when it comes to religious beliefs but can be associated with societal and cultural aspects (Park \& Aii, 2006). Participating religious activities can be associated with good mental health but on the other hand those faced persecution based on religion, in many instances it is not as good as for other groups. Sudanese refugees in Germany for instance prayed intensively for their country's situations to improve (Schweitzer et al., 2007). Khawaja and his colleagues did research on South Asian refugees in Australia, and he figured that during the transit, refugees always pray to get things better and to have changed their current situation and this way they found moments of peace. Many studies focused on refugees' life and their experience through religion and beliefs. Tibetan refugees in India make their presence by focusing both past and present life through religious practice and beliefs through Dalai Lama and Buddhism (Hussain \& Bhusan, 2013). Some Sudanese refugees for instance in Norway took their extreme traumatic situation as God will make them to heal that in future things will get better (Goodman, 2004).

Returning narratives appeared from both group of participants, and they keep focusing on family and friends. Loneliness and being all alone also somewhat preventing in coping with ne new environment while in exile. Aspects of community and family have been focused from the previous 
studies as part of coping mechanism as well. Children with their parents and other family members have sound mental health than those who arrived alone, stated by Fazel and his colleagues (2012), this study also stated that in the family environment those who discussed the conflict and war situations on their home countries have the chances to have children with mental issues than those who avoided discussing these previous incidences.

Support from social services, a family with extended members and community can function as to perform better and to resettle refugees into a new country context (Lim, 2009; East et al., 2010). Family reunion can be a matter of coping strategies, and they give the support both in mental and materiel context. In a study of refugees in Australia, Wilmsen (2013) presented many aspects that are negatively correlated while a refugee or a group of refugees are separated from their family members.

Family ties are also important as many studies also highlighted its importance. Intergenerational ties for instance has been described by Lewis (2010) in his study on Cambodian refugees to focus on how they became resilient to getting over societal and cultural gaps between the society that they are currently based in and their home country context.

Not having the chance to share experiences was mentioned by the participants. Sharing experiences, emotion among the family members have been highlighted by a study on refugees in Canada (Simich et al., 2014). Tamil refugees for instance in Norway were proactive in reducing future stress and to manage any strange situations by taking collective action (Guribye et al., 2011) Research on how refugees face their traumatic situation also highlighted on family ties and collective action. For instance, a study on Tamil refugees in Norway, Guribye et al. (2011) also described that refugees tried to absorb and heal any news in relation to deteriorating situation and more conflict in their country of origin. In a study of refugee women in Sweden, Boerema and her colleagues (2010) stated that weeding participation, wearing traditional dresses and enjoying parties in traditional ways and music also helps in settling a new society. 


\section{Conclusion}

In order to understand refugee families and how they adapt in a new society, memory and narratives play vital role in constructing 'their self' as Halbwachs (1980) in his study on refugees and their adaptation came up with the statement that it is important to focus on the participants memory and its significance to construct their narratives. Memories can be viewed as individual aspect; however, it has the importance of the social aspect as well (Teski \& Climbo, 1995). It is expected that refugees should cope with their host societies values and norm, in this process memories of past somewhat relegate and their present memories become more dominant (Bneezer, 2002). This study explored to address those memories and stories that have not been heard or listened, in order to come up with new narratives. Participants were really happy of sharing their experiences as it appeared the first time whom they could share their struggle during the war period and in exile. However, one significant outcome of this study is the lack of compatibility of the stories between two groups, through which five narratives established to elaborate the variety of their accounts. Concerning the coping mechanism and identity construction, different ways are identified from their narratives. From a collective point of view these narratives will enhance our understating of the refugee communities in Estonia and their ways of solving problem and coping mechanism.

\section{References}

Alexander, S. (1995). Becoming a woman. Verso.

Anderson, J. M., Reimer, J., Khan, K. B., Simich, L., Neufeld, A., Stewart, M., \& Makwarimba, E. (2010). Narratives of "dissonance" and "repositioning" through the lens of critical humanism: exploring the influences on immigrants' and refugees' health and well being. Advances in Nursing $\quad$ Science, 33(2), 101-112.

http://doi.org/10.1097/ANS.0b013e3181dbc56b

Andrews, M. (2004). Narrative Research. In C. D. Seale, J. Silverman \& G. Gobo (Eds.), Qualitative Research Practice (pp. 109-124). Sage. 
Appadurai, A. (1996). Modernity at large: cultural dimensions of globalization. University of Minnesota Press.

Berger, R. (2013). Now I see it, now I don't: Researchers position and Reflexivity in Qualitative research. Qualitative Research, 15(2), 1-16. http://doi.org/10.1177/1468794112468475

Boerema, C., Russell, M., \& Aguilar, A. (2010). Sewing in the lives of immigrant women. Journal of Occupational Science, 17(2), 78-84. http://doi.org/10.1080/14427591.2010.9686678

Bneezer, G. (2002). The Ethiopian Jewish exodus: narratives of the migration journey to Israel 1977-1985. Routledge.

Bruner, J. (1987). Life as narrative. Social Research, 54, 11-32.

Bryceson, D., \& Vuorela, U. (2002). The transnational family: new European frontiers and global networks. Berg.

Cavarero, A. (2000). Relating narratives: story telling and selfhood. Routledge.

Constance, R. S. (2004). Celebrating Ourselves: The Family Reunion Rituals of African-Caribbean Transnational Families. Journal of Transnational Affairs, 4(3), 243-257. http://doi.org/10.1111/j.1471-0374.2004.00091.x

Crossley, M. L. (2000). Narrative psychology, trauma and the study of self/identity. Theory and Psychology, 10, 527-546. http://doi.org/10.1177/0959354300104005

Dawson, G. (1994). Soldier heroes: British adventure, empire and the imagining of masculinities. Routledge.

East, L., Jackson, D., O’Brien, L., \& Peters, K. (2010). Storytelling: An approach that can help to develop resilience. Nurse Researcher, 17(3), 17-25. http://doi.org/10.7748/nr2010.04.17.3.17.c7742

Este, D. C., \& Tachble, A. (2009). Fatherhood in the Canadian context: Perceptions and experiences of Sudanese refugee men. Sex Roles, 60(78), 456-466. http://doi.org/10.1080/1754730X.2012.664858

Fazel, M., Reed, R. V., Panter-Brick, C., \& Stein, A. (2012). Mental health of displaced and refugee children resettled in high-income countries: Risk and protective factors. The Lancet, 379(9812), 266-282. http://doi.org/10.1016/S0140-6736(11)60051-2

Feuchtwang, S. (2003). Loss: transmissions, recognitions, authorisations. In S. Radstone \& K. Hodgkin, Regimes of memory (pp. 76-90). Routledge. 
Frank, A. W. (2010). The Wounded Storyteller: Body, Illness, and Ethics. University of Chicago Press.

George, S. (1992). Reflections on the Role of Social Narratives in WorkingClass Formation: Narrative Theory in the Social Sciences. Social Science History, 16(3), 489-516. http://doi.org/10.1017/S014555320001659X

Goffman, E. (2002). The Presentation of Self in Everyday Life. Doubleday. Goodman, J. H. (2004). Coping with trauma and hardship among unaccompanied refugee youths from Sudan. Qualitative Health Research, 14(9), 1177-1196. http://doi.org/10.1177/1049732304265923

Gleason, P. (1983). Identifying identity: a semantic history. Journal of American History, 69, 910-932. http://doi.org/10.2307/1901196

Guribye, E., Sandal, G. M., \& Oppedal, B. (2011). Communal proactive coping strategiesamong Tamil refugees in Norway: A case study in a naturalistic setting. International Journal of Mental Health Systems, 5(9), 1-13. http://doi.org/10.1186/1752-4458-5-9

Halbwachs, M. (1980). On collective memory. Harper \& Row.

Herman, J. L. (2001). Trauma and Recovery: From Domestic Abuse to Political Terror. Pandora.

Hoot, J. (2011). Working with very young refugee children in our schools: Implications for the world's teachers. Procedia Social and Behavioral Sciences, 1751- 1755. http://doi.org/10.1016/j.sbspro.2011.03.363

Hussain, D., \& Bhushan, B. (2013). Posttraumatic growth experiences among Tibetan refugees: A qualitative investigation. Qualitative Research in Psychology, 10(2), 204-216. http://doi.org/10.1080/14780887.2011.616623

Islam, A. (2016). Refugee Quota: Is Estonia Ready to Receive Refugees? A Review of the literature Migration and Ethnic Minorities in Estonia. International Multidisciplinary Journal of Social Sciences, 5(3), 281-297. http://doi.org/10.17583/rimcis.2016.2225

Josselson, R. (2011). Narrative Research Constructing, Deconstructing and Reconstructing Story. In F. J. Wertz, K. Charmaz, L. M. McMullen, R. Josselson, R. Anderson \& E. McSpadden (Eds), Five Ways of Doing Qualitative Analysis (pp. 224-242). Guildford Press. 
Kacen, L., \& Chaitin, J. (2006). The times are a changing: understanding qualitative research in ambiguous, conflictual and changing contexts. Qualitative Report, 11, 209-228.

Keyes, E. F., \& Kane, C. F. (2004). Belonging and adapting: Mental health of Bosnian refugees living in the United States. Issues in Mental Health Nursing, 25(8), 809-831. http://doi.org/10.1080/01612840490506392 Labov, W. (2008). Oral Narratives of Personal Experience. In Cambridge Encyclopedia of the Language Sciences. Cambridge University Press.

Lewis, D. C. (2010). Cambodian refugee families in the United States: "Bending the tree" to fit the environment. Journal of Intergenerational Relationships, 8(1), 5-20. http://doi.org/10.1080/15350770903520635

Leydesdorff, S. (2000). Gender and the categories of experienced history in D. Davidoff, K. McClelland \& E. Varakis (Eds.), Gender and history: retrospect and prospect (pp. 179-194). Blackwell Publishers.

Lim, S.-L. (2009). Loss of connections is death: Transnational family ties among Sudanese refugee families resettling in the United States. Journal of Cross-cultural Psychology, 40(6), 1028-1040. http://doi.org/10.1177/0022022109346955

Linde, C. (1987). Explanatory systems in oral life stories. In D. Holland \& N. Quinn (Eds.), Cultural models in language and thought (pp. 343-366). Cambridge University Press.

Lucky, R., David, G., \& James, O. (2015). Syria: The story of the conflict. BBC News.

Nussbaum, M. C. (2001). Upheavals of thought, the intelligence of emotions. Cambridge University Press.

Obrist, B., \& Büchi, S. (2008). Stress as an idiom for resilience: Health and migration among sub-Saharan Africans in Switzerland. Anthropology and Medicine, 15(3), 251-261. http://doi.org/10.1080/13648470802357596

Park, C. L., \& Ai, A. L. (2006). Meaning making and growth: New directions for research on survivors of trauma. Journal of Loss and Trauma, 11(5), 389-407. http://doi.org/10.1080/15325020600685295

Passerini, L. (2003). Memories between silence and oblivion. In K. Hodgkin \& S. Radstone (Eds.), Contested pasts: the politics of memory (pp. 238254). Routledge. http://doi.org/10.4324/9780203785751 
Richie, B. (1995). Racism, ethnic stigma and gender violence: exploring the intersections of oppression. Plenary Midwest Conference on Child Abuse and Incest, University of Wisconsin, Madison, WI, 9 November.

Riessman, C. K. (2008). Narrative Methods for the Human Sciences. Sage Publications.

Roxas, K. C. (2011). Creating Communities: Working with Refugee Students in Classrooms. Democracy and Education, 19(2). http://doi.org/10.7748/nop.27.1.41.s22

Schweitzer, R., Greenslade, J., \& Kagee, A. (2007). Coping and resilience in refugees from the Sudan: A narrative account. Australian and New Zealand Journal of Psychiatry, 41(3), 282-288. http://doi.org/10.1080/00048670601172780

Simich, L. (2014). Editor's introduction. In L. Simich \& L. Andermann (Eds.), Refuge and resilience (pp. 1-6). Springer Netherlands.

Sorsoli, L. (2010). Echoes of Silence: Remembering and Repeating Childhood Trauma. In A. Lieblich, D. P. McAdams \& R. Josselson (Eds.), The Narrative Basis of Psychotherapy (pp. 89-109). American Psychological Association.

Spector-Mersgel, G. (2011). Mechanisms of Selection in Claiming Narrative Identities: A Model for Interpreting Narratives'. Qualitative Inquiry, 17(2), 172-185. http://doi.org/10.1177/1077800410393885

Tammaru, T., Haukanomm, K., \& Anniste, K. (2010). The formation and development of the Estonian diaspora. Journal of Ethnic and Migration Studies, 36(7), 1157-1174.

http://doi.org/10.1080/1369183X.2010.481614

Teski, M. C., \& Climo, J. J. (1995). The labyrinth of memory: ethnographic journeys. Bergin \& Garvey.

Thompson, P., \& Bauer, E. (2005). Sources of Aid and Resilience and Points of Pain in Jamaican Migrant Families. Revue Europeenne Des Migrations Internationales, 21(3). http://doi.org/10.4000/remi.2502

Thornberg, R., \& Charmaz, K. (2014). Grounded Theory and Theoretical Coding. In U. Flick (Ed.), Sage Handbook of Qualitative Analysis. (pp. 153-169). Sage. http://doi.org/10.4135/9781446282243.n11

Tonkin, E. (1992). Narrating our pasts: the social construction of oral history. Cambridge University Press. 
UNHCR (2018). The Global Report on Refugees.

Ward, S. (2003). On Shifting Ground: Changing Formulations of Place in Anthropology. The Australian Journal of Anthropology, 14(1), 80-96. http://doi.org/10.1111/j.1835-9310.2003.tb00222.x

Weingarten, K. (2003). Common shock: Witnessing violence every day: How we are harmed, how we can heal. Dutton/Penguin Books.

Wilmsen, B. (2013). Family separation and the impacts on refugee settlement in Australia. Australian Journal of Social Issues, 48(2), 241262. http://doi.org/10.1002/j.1839-4655.2013.tb00280.x

William R. P. (2013). Understanding Syria: From Pre Civil was to Post Asad. The Atlantic, December, 10.

Aminul Islam is Head of The Curriculum for Creativity and Innovation Program at the Estonian Entrepreneurship University of Applied Sciences and PhD Student at the Institute of International and Social Studies at the Tallinn University.

Email: aminulislam80@yahoo.com, aminul@tlu.ee 